\title{
PROPERTY LAW: THE ESTATES OF MISSING PERSONS
}

This comment compiles and critically analyzes the various statutory provisions enacted for the preservation and distribution of the property of missing and unaccounted-for persons. Special emphasis is given the recently enacted North Carolina statute because of its enlightened and comprehensive approach.

T HE PROBLEMS inherent in the handling of property owned by one who has disappeared and remained absent without explanation are both numerous and difficult. As long as it is not known whether he is living or dead, rights must remain uncertain and his property is rendered virtually useless. The obvious need to satisfy the interests of the absentee's family and creditors and to keep property in the stream of commerce while at the same time protecting the absentee from the dissolution of his estate led to the enactment of remedial legislation in a number of states. ${ }^{1}$

The early attempts to provide statutory relief, ${ }^{2}$ however, were limited to general probate administration of the estate after a certain period of absence which corresponded with the time the ab-

\footnotetext{
${ }^{1}$ For a general discussion of the states having such legislation and their varying provisions, see Committee on Administration of Property of Infants, Incompetents and Missing Persons, Report, 102 Trusts \& Estates 908 (1963).

3 There seems to be a dearth of authority on the judiciary's power, apart from statute, to act for the purpose of conserving and protecting the property of a missing person. In Webster v. Franklin County Trust Co., 313 Mass. 401, 47 N.E.2d 934 (1943), the Probate Court dismissed a petition in equity for the appointment of a successor receiver to manage the property of an absentee, asserting that "the appointment of receivers of the property of absentees and the distribution of the property are provided for by statute. . . Those subject matters are not within the scope of equity jurisprudence... [but] must be dealt with on the probate side of Probate Court and not in equity." $I d$. at 403,47 N.E.2d at 936 . The court did, however, note that although the statute did not contain a provision authorizing the appointment of a substitute receiver to succeed one who had died, "such authority is inherent in the Probate Court, and necessarily incidental to the accomplishment of the purposes of the statute . ..." Id. at 404,47 N.E.2d at 936 .

A dictum in In re Safris, 112 F. Supp. 146 (D.N.J. 1953), intimated that the court might perchance have the authority "under its general equity powers, to conserve and protect the property of a missing person." Id. at 146. At least one commentator has expressed the view that "it is likely that a Court of Equity has inherent power, even in the absence of statute, to provide for the preservation of the property of and the support of the dependents of missing persons." Gray, Trust Problems in Connection with the War, 16 CoNN. B.J. 347, 354 (1942).

Courts have occasionally relied on equity jurisdiction to authorize certain acts performed by the trustee for an absentee which otherwise might be outside the pale of the statute. See note 54 infra.
} 
sentee was presumed dead. The relief afforded by these statutes was often rendered nugatory because of the rigid but well-accepted principle that the foundation for that probate jurisdiction rests exclusively upon death. ${ }^{3}$ Thus, the Supreme Court in Scott $v$. Mc$\mathrm{Neal}^{4}$ held that subsequent proof of the continued life of the absentee retroactively destroyed the court's jurisdiction; the appointment of the administrator and all acts performed by him or others in reliance on the court's jurisdiction were deemed violative of due process and void. 5

It has been suggested that there is no tenable basis for the Scott decision at the present time. ${ }^{6}$ Arguably, American probate courts are courts of record and should therefore have the power to pass upon the questions of fact which determine whether they have jurisdiction. If a court is possessed of this power, it would follow that an erroneous determination should not void the entire judgment $a b$ initio. ${ }^{7}$ Despite such contentions, however, the Scott precedent is still extant, and states endeavoring to cope with the absentee problem must frame their solutions to comport with the due process requirements enunciated by the Court. Most states have now enacted special statutes relating to the estates of missing persons in an attempt to meet the requisites of due process. In the first case to test such a statute, Cunnius v. Reading School Dist., ${ }^{8}$ the Supreme Court

${ }^{3}$ Griffith v. Frazier, 12 U.S. (8 Cranch) 9, 23 (1814); In the Matter of Estate of Paulsen, 179 Cal. 528, 178 Pac. 143 (1918); Springer v. Shavender, 118 N.C. 33, 23 S.E. 976 (1896). See 41 Colum. L. Rev. 744 (1941); 43 HARv. L. Rev. 485, 486 (1930).

+154 U.S. 34 (1894).

- The absentee in Scott alleged that the administrator's receipt of money from a debtor of the absentee would not discharge the debt and that the administrator's conveyance of property would pass no title. Id. at 35 . The fundamental question involved was whether letters of administration issued upon the estate of a person who is in fact alive have any validity. Id. at 39 . The Supreme Court held that the presumption of death derived from continued absence was only presumptive evidence of death. The Court reasoned that since the only jurisdiction of a probate court is over the estate of a dead man, when the continued life of the supposed decedent rebuts the presumption there is no ground for sustaining the jurisdiction of the court. Id. at $48-49$.

Similarly, as jurisdiction rests upon the fact of death, the notice given assumes that fact and is not addressed to the absentee but to those interested in his estate. No judgment of a court can accord with due process of law if rendered without jurisdiction in the court or without notice to the interested party, and the court deemed both elements to be lacking in the case of the reappearing absentee. Id. at 49-50. See also Bcckwith v. Bates, 228 Mich. 400,200 N.W. 151 (I924).

- See 3 American Law of Property \$ 14.3, at 562 (1952).

I Ibid.

8198 U.S. 458 (1905). The Cunnius Court disposed of the Scott case by stating that the opinion in that case did not imply that states are without power to provide 
held that it was within the states' police power to provide their courts with jurisdiction to administer the estates of absentees by special proceedings, ${ }^{9}$ provided these proceedings prescribed a reasonable period of absence, afforded adequate notice and protected the absentee's interests should he in fact be alive. ${ }^{10}$ Where these requirements are satisfied, the statutes have generally been upheld.11

The purpose of this comment is to examine current statutes relating to estates of absentees. It is divided into two parts. Part I will undertake a review of those sections of the statutory schemes which provide for the conservation of the absentee's property and discharge of his obligations during his absence. Part II examines those provisions which supply the machinery for determining the death of the absentee and for the ultimate distribution of his estate. Because many of the provisions of the newly enacted North Carolina statute $^{12}$ represent major advances over both the prior law in North Carolina and most of the presently existing law in other jurisdictions, special emphasis will be placed on this statute where it is warranted in the hope that this approach will emphasize the need and provide guidelines for the enactment of similarly enlightened legislation.

\section{Part I. Conservation of Property of Absentees}

Pursuant to the typical conservatorship provision, a probate court, upon application of an appropriate party, may appoint an individual who will exercise designated powers in behalf of the absentee. The primary purpose of such a provision is the conserva-

their courts with jurisdiction to administer the estates of absentees who might in fact be alive when they did so by special and appropriate proceedings. Id. at 473 . On the contrary, the Court viewed Scott as holding only that, absent special legislation and under a law giving probate courts jurisdiction to administer the estates of deceased persons, the court was without jurisdiction if the presumption of death after a stipulated period of absence was later rebutted by proof of the absentee's being alive. Ibid. See 25 So. CAL. L. REv. 447 (1952).

- The pattern of the special statutes diverges from that of the general laws relating to the distribution of a deceased person's estate. The general laws employ the state's probate jurisdiction, whereas under the special provisions the state's police power is being exercised for the reason that "property without a known owner should be conserved by the state having jurisdiction over it." Lees, Property Rights of Persons Who Have Disappeared, 9 MrN. L. REv. 89, 93 (1925).

${ }^{10} 198$ U.S. at $476-77$.

12 See, e.g., Blinn v. Nelson, 222 U.S. 1 (1911); Stevenson v. Montgomery, 263 Ill. 93, 104 N.E. 1075 (1914); Walz v. Dawson, 235 Mich. 344, 209 N.W. 177 (1926). See generally Sevier v. Bank of America Nat. Trust \&. Sav. Ass'n, 101 Cal. App. 2d 184, 225 P.2d 3 (Dist. Ct. App. 1950); In re Nelson's Estate, 37 Wash. 2d 397, 224 P.2d 347 (1950).

${ }^{12}$ N.C. Gen. Stat. $§ \$ 28 A-1$ to -22 (Supp. 1965). 
tion of property. ${ }^{13}$ Accomplishment of this objective inures to the benefit of the state as well as to the absentee or those who would have an interest should he not return. The state legitimately has both a paternal interest in protecting the property of a citizen who is unable to do so himself and a sovereign interest in preventing the deterioration of property located within the state bounds. ${ }^{14}$ Other objectives may also be perceived in many of the statutes and include such salutary purposes as the support and maintenance of dependents of the absentee. ${ }^{15}$

Although some states have unique conservator provisions, the fundamental structure of the various statutory schemes is basically the same. For that reason, Part I will consist of a general statutory survey designed to indicate and assess the elements likely to be found in the typical statute.

\section{JURISDICTIONAL REQUIREMENTS}

Residence of absentee: To invoke judicial jurisdiction under these statutes, it is initially necessary to determine whether the missing person must satisfy a residence requirement before he can qualify as an absentee under the statute. Approximately one-third of the statutes require that the missing person be a resident of the state before the jurisdiction of the appropriate court may be invoked. ${ }^{18}$ The remaining states require only that the absentee be

\footnotetext{
${ }^{13}$ Marshall v. Marshall, 159 Kan. 602, 606, 156 P.2d 537, 539 (1945); Leahy v. Wayne Probate Judge, 227 Mich. 40, 45, 198 N.W. 432, 433 (1924).

14 Cf. Georgia v. Tennessee Copper Co., 206 U.S. 230, 237 (1907).

${ }^{18}$ See note 67 infra and accompanying text.

${ }^{16}$ E.g., Cal. Prob. Code $\S 260 ;$ Ga. Code ANN. $\S 113-2701$ (1959); Neb. Rev. Stat. $\S 30-2001$ (1964); Nev. Rev. Stat. $\S 156.010$ (1959); R.I. Gen. LAws ANN. $\$ 33-20.1$ (1956); Wyo. Stat. ANN. § 4-27 (1957).

The New York statute requires that the absentee be a person whose estate, were he dead, would be subject to the jurisdiction of the surrogate. N.Y. SURR. CT. AcT $\$ 126$.

This requirement appears similar in effect to the UNIFORM AnSENGE As EvidENGE OF Death and Ansentees' Property Act $\$ 3$, which has been adopted in Maryland, MD. ANn. Code art. 16, § 202 (1) (1957), Tennessee, TENn. CODE ANN. $\$ 30.1804$ (1955), and Wisconsin, WIS. STAT. ANN. $§ 268.23$ (1) (a) (1957), and makes "domicile" the crucial factor.

The stringency of the requirement of proof of residence in California was indicated in In the Matter of Estate of Lowe, 19 Cal. App. 2d 271, 65 P.2d 113 (Dist. Ct. App. 1937), where the court stated that the language of the statute "admits of no conclusion other than that before any legal action with reference to the administration of the estate of such a person may be taken or had, the fact must be established that he was (or is), a 'resident of this state'; and of course, in order that such fact may properly, regularly, and legally be made to appear, it must not only be pleaded and proved, but as well, must be so adjudicated. In other words, that fact constitutes a jurisdictional element in the proceedings;-in the absence of which no legal order
} 
owner of property within the boundaries of the state. ${ }^{17}$ The residence requirement may be justified as a method of insuring that the absentee and his dependents will be more surely afforded adequate notice of the conservatorship imposed, but any statute must meet minimum standards providing such insurance. On balance, the property ownership requirement is perhaps a more desirable provision in view of the conservational purpose which has been interposed as the primary justification of absentee statutes. ${ }^{18}$

Length of absence: Most states require proof that the absentee has been missing and unheard of for a certain length of time, ${ }^{10}$ and in at least two states the mere fact of absence for a designated period will, without more, justify judicial action. ${ }^{20}$ Although the newly enacted North Carolina statute requires an absence of only thirty days, ${ }^{21}$ the period prescribed may vary from three months to three years. ${ }^{22}$ In several states, no stipulated "period" of absence is necessary to invoke the statute ${ }^{23}$ and ostensibly the question of indefinite and unexplained absence becomes one of fact. It is suggested that due regard for the conservation of the property and the protection of dependents militates in favor of a shorter absence

in the premises may be made." Id. at 275, 65 P.2d at 114 . Cf. In re Curran, 94 N.J. Eq. 723, 120 Atl. 786 (Prerogative Ct. 1923).

${ }^{17}$ E.g., ConN. Gen. Stat. ANN. \$ 45-87 (1960); Fla. STat. § 747.01 (2) (1963); IDaho CODE ANN. § 15-210I (1948); IowA CODE $§ 633.580$ (1964); KY. REv. STAT. $\$ 395.410$ (2) (1960).

${ }^{18}$ See notes 13-15 supra and accompanying text.

${ }^{10}$ In Day v. Metropolitan Life Ins. Co., 11 Cal. App. 2d 681, 54 P.2d 502 (Dist. Ct. App.), cert. denied, 299 U.S. 560 (1936), the court rejected a constitutional challenge that a ninety-day absence was too short a time limitation to be consistent with due process. The challenge was made by an insurance company which was objecting to the efforts of a trustee appointed for the absentee to exercise a conversion option in the policies. The court stated that the question of an appropriate period of absence is "purely legislative" and that a court cannot substitute its opinions for the legislative judgment "unless the unconstitutionality of the statute is so apparent on the face that no circumstances can be assumed under which it might have a constitutional operation." II Cal. App. 2d at 683, 54 P.2d at 503.

so IDAHo CODE ANN. $\$ 15-2102$ (1948); N.J. STAT. ANN. $\$ 3 A: 39-1$ (1953).

21 N.C. GEN. STAT. \$ 28A-2 (a) (Supp. 1965).

${ }_{23}$ The most common period of absence utilized is three months. E.g., CAL. ProB. Code $\S$ 260; GA. Code ANN. $\$ 113-2701$ (1959); Mich. CoMp. LAws $\S 705.29$ (1948); Minn. Stat. ANN. $\$ 576.04$ (1947); NEb. Rev. Stat. \$ 30-2001 (1964). Some states, however, require an absence of one year. E.g., KY. REv. STAT. $\$ 395.410(2)$ (1960); N.H. Rev. Stat. ANN. § 553:18 (1955); N.J. Stat. ANN. § 3A:39-1 (1953); PA. Stat. ANN. tit. $20, \S 320.1202$ (1950); R.I. GEN. LAwS ANN. $\S 33-20-1$ (1956). Other states may require even longer periods of absence. E.g., D.C. ConE ANN. $\$ 20-701$ (1961) (two years, alternative provision); VT. STAT. ANN. tit. 14, $\$ 2305$ (1958) (three years, alternative provision).

${ }^{23}$ E.g., Fla. Stat. $\$ 747.01$ (1963); Iowa CoDE $\$ 633.580$ (1964); Mass. GeN. LAwS ANN. ch. 200, § I (1955); WASH. REv. CODE $\S 11.80 .010$ (1956). 
period, although the statutes which stipulate no requisite lapse of time may be even better equipped to achieve these ends since they may be invoked as soon as the absence and the need for conservatorship become apparent.

Other jurisdictional requirements: In addition to possible residence and length of absence requirements, most states impose additional jurisdictional requisites of proof relating to the circumstances surrounding the disappearance or to other facts existing at the time of or subsequent to the disappearance. Such statutory demands vary significantly from state to state. A few states require proof of disappearance under circumstances which indicate or lead to the conclusion that the absentee is dead or that his absence is due to insanity or amnesia. ${ }^{24}$ A specific showing may be required as proof

\footnotetext{
24 FLA. STAT. \$747.01 (a) (1963) (circumstances indicating death or disappearance as result of mental derangement or amnesia); GA. CODE ANN. $\$ 113.2701$ (1959) (circumstances leading to conclusion of death); N.H. REv. STAT. ANN. § 553:18 (1955) (judge believes absentee to be dead); OHIO REv. CoDE ANN. \$2119.01 (Page 1954) (circumstances affording reasonable ground for belief that he is dead, cannot return, or refuses to return); VT. STAT. ANN. tit. 14, $\S 2305$ (1958) (circumstances satisfying probate court of reasonable ground for belief that he is lost, insane or dead).

The New York statute requires a disappearance "under circumstances, which afford reasonable ground to believe either that he is dead, or that he has become a lunatic, or that he has been secreted, confined, or otherwise unlawfully made away with, or that he has been made a prisoner of war or has been detained or interned by an enemy country or in an enemy-occupied country ... ." N.Y. SURR. CT. ACT \$ 126 (2). Prior to a 1961 amendment, the New York courts were vigorous in their requirement that the circumstances indicate death. In re Ostromislensky's Estate, 110 Misc. 189, 180 N.Y. Supp. 267 (Surr. Ct. 1920).

In Germain v. Germain, 31 Misc. 2d 401, 220 N.Y.S.2d 1013 (Sup. Ct. 1961), the court sympathized with the wife of an absentee who was forced by the rigors of the absentee property statute to petition for separation from her husband in order to protect the property. The court stated that under the provision "the circumstances of the disappearance must indicate death and be inconsistent with his being alive. While the defendant here may be dead, the circumstances under which he disappeared are not inconsistent with his still being alive. He could be either. The prestimption of life must therefore control." Id. at 405, 220 N.Y.S.2d at 1016. (Emphasis added.) An appeal by the Germain court to the legislature for remedial action was answered by enactment of the 1961 amendment, which changed the statute by adding the provision that "for the purposes of this subdivision, circumstances affording reasonable ground to believe that an event described in this paragraph has occurred include circumstances pertaining to the behavior, habits and situation of the missing person before his disappearance and the absence of known facts providing a different explanation for the disappearance and the failure of diligent search to discover the abode of the missing person." N.Y. SURR. CT. ACT. $\$ 126(2)$. Subsequent to passage of the amendment, in In re Mathiez' Estate, 38 Misc. 2d 498, 237 N.Y.S.2d 33 (Surr. Ct. 1968), evidence of disappearance and a fruitless search was held sufficient to indicate a showing of death. The court said that a broader interpretation of the statute would thereafter be recognized in light of the effort by the legislature to loosen the jurisdictional requirement.

Henley v. Wadleigh, 88 N.H. 174, 186 Atl. 505 (1936), involved the New Hampshire
} 
that the property needs supervision ${ }^{25}$ or that without supervision it is likely to be lost or damaged. ${ }^{26}$ Also, proof of a diligent search or inquiry into the absence is demanded by some states. ${ }^{27}$ Finally, a few jurisdictions have statutory provisions especially designed to indicate circumstances which will justify the appointment of a representative for a missing serviceman. ${ }^{28}$

To be sure, the unnecessary appointment of a representative for an absentee is undesirable. But experience has indicated that rigorous adherence to overly strict requirements as to circumstances of disappearance may render the conservator provision useless in ameliorating the hardships at which it was directed. ${ }^{20}$ The revised North Carolina statute, for example, now permits the appointment whenever "after diligent inquiry ... [the absentee's] whereabouts remain unknown to those persons most likely to know the same ...."30

Special provisions-absentee need not be "missing": In a commendable effort to protect abandoned families, four states have pro-

statute. The court in that case refused to permit the administrator to take into his possession property which had been held by the absentee as a life tenant. The court said that to permit this would be in derogation of the belief upon which the validity of the appointment of the administrator depended; namely, that the absentee was dead. The court also held that the remaindermen were not entitled to the property since they "may not regard the death to be established. . . . So far as relates to their title, the probate court's belief, and consequent finding, of the life tenant's deatb is ... of no effect in determining its [life estate's] termination." Id. at $176,186 \mathrm{Atl}$. at 506 .

${ }^{30}$ E.g., Del. CODE ANN. tit. 12, § 4101 (1953); Nev. Rev. STAT. § 156.010 (1959); N.Y. Surr. CT. Acr \$ $126(2) ;$ ORE. REv. StAT. \$ 127.010 (1963). The New York requirement that the appointment be necessary "for the protection of his [absentee's] property" was found wanting in In re Ostromislensky's Estate, supra note 24.

${ }^{28}$ E.g., Mich. CoMp. Laws $\$ 705.29$ (1948). In Leahy v. Wayne Probate Judge, 227 Mich. 40, 198 N.W. 432 (1924), the court rejected a petition for appointment under the Michigan statute because "there is no proof that her [absentee's] property is going to waste or is in danger of being destroyed or lost for want of a proper custodian." Id. at 45, 198 N.W. at 433 .

${ }^{37}$ E.g., Conn. GEN. Stat. ANN. $\$ 45-87$ (1960) (diligent search is presumed to have been made for a missing serviceman); N.C. GEN. STAT. $\$ 28 \mathrm{~A}-2$ (Supp. 1965) (diligent inquiry); Uniform Absence as Evidence of Death and Absentees' Property Act $\$ 3$.

${ }_{28}$ These statutes typically require that the missing person be "reported or listed as missing, missing in action, or interned in a neutral country, or beleaguered, besieged or captured by an enemy ...." ARIz. REV. STAT. ANN. § 14-871 (1956); Del. Code AnN. tit. 12, 4101 (1953); Hawali Rev. Laws $\S 338-21$ (1955); IND. ANN. STAT. $\$ 7-2307$ (1953).

For a discussion of the problem created by war and application of the war absentee statutes, see Gray, supra note 2, at 352-57. Gray suggests as an alternative to the statutes that the departing serviceman give a general power of attorney to someone to act in his behalf. Id. at 355 .

${ }^{29}$ See note 24 supra.

${ }^{30}$ N.C. GEN. StAT. § 28A-2 (a) (Supp. 1965). 
vided that a receiver may be appointed for the property of a person who has left the state without having made provision for the support of a dependent wife or minor children even though his whereabouts may be known. ${ }^{31}$ Provided that proper notice is afforded the deserter, such a provision seems eminently desirable as a protective device.

\section{Proper Applicants}

In one respect, a measure of the possible utility of an absentee property statute is the extent to which persons with a legitimate interest in the property of an absentee are accorded the right to invoke the statute. A few states have no limitation on the persons who may properly petition the court to make an appointment, and anyone from a needy spouse to an officious intermeddler may make the application ${ }^{32}$ In other states the coverage is less broad and only specifically described parties such as family members and creditors may invoke the statute. ${ }^{33}$ Whether a person is qualified to petition the court may necessitate reference to statutes other than the "absentee" provision. Thus, in a few states a petition may be filed by one who would be entitled to administer the property of the absentee were he deceased ${ }^{34}$ or who would be authorized to act as guardian..$^{35}$ Further, in some states, the court on its own motion is empowered to execute the statute ${ }^{36}$ and presumably this would enable a person who would otherwise not qualify as a petitioner to provide the impetus for judicial action.

It is submitted that as regards proper applicants, the broader the statute the better. The situations are numerous in which people in different capacities would have a legitimate interest in seeing that an absentee's property is cared for, his dependents maintained, or his

\footnotetext{
${ }^{31}$ D.C. Code ANn. $\$ 20-701$ (1961); ME. Rev. Stat. ANN. tit. 18, § 2751 (1964); Mass. Gen. Laws ANn. ch. 200, $\$ 1$ (1955); MinN. Stat. ANN. $\$ 576.04$ (Supp. 1965).

${ }^{32}$ E.g., IDAHo CODE ANN. \$ 15-2104 (1948); IOWA CODE $\$ 633.510$ (1964); Wasil. Rev. CODE $\S 11,80.010$ (1956); Wyo. STAT. ANN. \$ 4-27 (1959).

${ }^{33}$ E.g., CAL. Prob, CODE $\$ 260$ (wife, family member, friend); Hawair Rev. LAws $\S 338-21$ (1955) (any person who would have an interest in property of absentec on his death); Mrch. Comp. LAws $§ 705.29$ (1948) (wife, next of kin, creditor); Neb. REv. Stat. \$ 30-2001 (1965) (wife, family member, friend); NEv. Rev. Stat. \$ 156.010 (1959) (family member, friend); OHro REv. CodE ANN. \$ 2119.01 (Page r954) (spouse, next of kin); ORE. REv. STAT. § 127.010 (1963) (family member, business associate, friend).

36 E.g., D.C. Code ANN. § 20-701 (1961); N.C. GEN. STAT. § 28A-2 (Supp. 1965).

sE Miss. CODE ANN. $\S 450-01$ (1957).

${ }^{36}$ E.g., ARIz. Rev. STAT. ANN. \$ 14-871 (1956); DeL. Code ANN. tit. 12, $\$ 4101$ (1953); Fla. STAT. $\$ 747.02$ (1963); UtAh CODE ANN. $\$ 75 . T-9$ (1958).
} 
debts paid. So long as action upon conservator petitions is within the discretion of the court, there would appear to be little objection to a statute which places no limitations upon the class of persons who may file. The courts, aided by the particular jurisdictional requirements, in a given state, are generally equipped to dispose of those petitions which are intended as nuisances or are otherwise without merit in the particular circumstances of the case.

\section{Notice Provision}

Although a few statutes have no express provision for notice of conservatorship proceedings, ${ }^{37}$ most of the states require that notice be given of an application for an appointment of a representative and of the date on which the application will be heard. The requirement in many states is satisfied by the publication of the notice, addressed to the public, in a designated local newspaper or legal journal. ${ }^{38}$ A few states require that copies of the notice be posted in a conspicuous place or on each parcel of land belonging to the absentee. $^{30}$ Such perfunctory notice would in all likelihood be of primary benefit to creditors, and more direct notice to the absentee and his family is required by some provisions. A common requirement is that a copy of the notice be mailed to his last known address.40 The Uniform Absence as Evidence of Death and Absentees' Property Act ${ }^{41}$ and the North Carolina statute ${ }^{42}$ require, in

${ }^{87}$ See, e.g., ARIz. Rev. Stat. ANN. \$§ 14-871 to -873 (1956); DEL. Code ANN. tit. 12, §§ 4101-03 (1953); N.J. STAT. ANN. \$§ 3A:39-1 to -4 (1953); UTAH CoDE ANN. § 75-1-9 (1953). No cases have been discovered which raise the issue of the sufficiency of prescribed notice to satisfy due process requirements in connection with purely conservatorship proceedings. Presumably, less would be constitutionally required in this type proceeding, which is aimed at protecting the absentee's property, than where a final distribution is being made.

${ }^{38}$ E.g., Gal. Prob. Code § 261; Neb. Rev. Stat. § 30-2001 (1964); Nev. Rev. Stat. $\S 156.020$ (1959). See Cunnius v. Reading School Dist., 198 U.S. at 459, 476-77.

so E.g., D.C. CODE ANN. $\$ 20-704$ (1961) (copy posted in conspicuous place and upon each parcel of land); MAss. GEN. LAwS ANN. ch. 200, §4 (1955) (posted in two or more conspicuous places in town where absentee last resided and upon each parcel of land).

so E.g., Ky. REv. Stat. \$ 395.430 (2) (1960); R. I. Gen. LAws ANN. \$ 33-20-2 (1956).

A few states also demand more particular notice to other interested parties. E.g., OHo REv. CoDE ANN. \$ 2119.02 (Page 1954) (copy of notice mailed to spouse and next of kin in the state).

11 Unifora Absence as Evidence of Death and Absentees' Property Act $\$ 3$ (absentee shall be named as a party; any person who would have an interest were the absentee deceased may, upon direction of the court, be made party).

12 N.C. GEN. STAT. \$ 28A-2 (c) (Supp. 1965). This statute provides for the following parties to a conservatorship action: "the absentee, all persons who would have an interest in the estate of such absentee if he were deceased, all persons known to 
addition, that the absentee and all persons interested in the estate be named as parties to the action to insure not only notice but also a binding decree which the absentee may not collaterally attack subsequently. Further, during the period of management, additional notice may be required prior to the exercise of certain powers by the appointee. ${ }^{43}$

Although it would appear somewhat futile, all precautions should be taken to afford fair and adequate notice to the absentee as well as his creditors and kin. One possible method of insuring adequate notice would be to couple the "diligent search" requirement, imposed by some states as a prerequisite to jurisdiction, ${ }^{44}$ with notice by publication and also by service.

\section{Aprointee-Qualifications and Prefferences}

A few statutes stipulate that the appointee ${ }^{45}$ must be of legal age and a resident of a specified area or must be a person who would be qualified to act as administrator or executor of the probate estate of the absentee. ${ }^{46}$ Often, the spouse of the absentee or her nominee is preferred over other potential appointees. ${ }^{47}$ Such provisions appear to be overly bound by traditional probate-administrator concepts framed with a view to distribution of the assets of a decedent. Such analogies are not well equipped to serve the conservational purpose of the absentee acts, many of which may be invoked upon a thirty-day absence. ${ }^{48}$ This period is much shorter than most pre-

claim an interest in the absentee's property, and all known insurers of the life of the absentee ...." Ibid.

${ }^{13}$ For example, notice may be required and a hearing held prior to authorization of the sale of absentee's property. See note 62 infra and accompanying text.

"See note 27 supra and accompanying text.

16 The individual appointed by the court to act for the absentee will be desig. nated by one of the many titles used by the various states. Conservator and trustee are the most frequently employed names. E.g., Cons. GEN. STAT. ANN. \$ 45.87 (1960) (trustee); FlA. STAr. \$ 747.02 (1963) (conservator); GA. CODE ANN. § 113.2701 (1959) (conservator); N.J. STAT. ANN. \$ 3A:39-1 (1953) (trustee).

Other titles include: Araska Stat. $\$ 20.05 .130$ (1962) (guardian); Ky. Rev. Stat. $\S 395.410$ (2) (1960) (curator); Mich. CoMp. Laws $\$ 705.29$ (1948) (special administrator); N.H. REv. Stat. ANN. § 553.18 (1955) (administrator); N.Y. SurR. CT. Act. § 126 (2) (temporary administrator); N.C. GEN. STAT. \$ 28A.6 (Supp. 1965) (receiver).

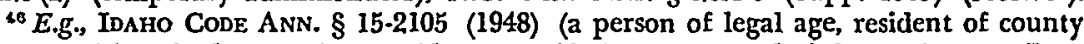
where petition filed and who would be qualified to act as administrator); OrE. REv. STAr. $\$ 127.040$ (1953) (person resident of county in which the application was made and who has qualifications prescribed for an executor or administrator).

ir E.g., Cal. Prob. Code \$ 263; Minn. Stat. ANN. \$ 576.08 (1947); Nev. Rev. Stat. $\S 156.040$ (1959).

${ }^{4}$ See notes $19-23$ supra and accompanying text. 
sumption of death limitations, ${ }^{49}$ and is thus quite remote from the time of distribution. The Washington statute is therefore both unique and salutary in admonishing the court that the appointment shall be made "taking into consideration the character of the property and the fitness of such trustee to care for the same ...." "so

Other provisions have been designed to cope with special problems which may arise concerning the administration of certain kinds of estates and property. For example, North Carolina has a commendable provision for appointment of the county public administrator if the fair market value of the estate is less than 1,000 dollars." In the words of the draftsmen: "The purpose of this section is to reduce unnecessary delay and expense to small estates by utilizing the office of public administrators which provides an inexpensive means of disposing of such estates."52 Further, in a few states, a temporary appointment may be made pending a hearing on the petition for a permanent appointment if it is necessary for the protection of the property. ${ }^{53}$ This latter type of provision would be especially desirable to facilitate the management of operating business enterprises necessitating immediate attention.

\section{Powers of Appointee}

The authority which is vested in a person appointed to act in behalf of the absentee should be comprehensive enough to enable him to effectuate the policies of the statute and should be sufficiently subject to the rigors of judicial supervision so as to afford

${ }^{4}$ Common presumptions of death take effect after five to seven years following unexplained absence. See notes 92-94 infra and accompanying text.

${ }^{\circ}$ WASH. Rev. CODE $\S 11.80 .010$ (1956).

E1 N.C. Gen. Stat. § 28A-17 (Supp. 1965).

62 General Statutes Comm'n, Speclal Report on an Act to Add to the General Statutes Chapter 28A to be Entitled "Estates of Missing Persons" 22 (1965) [hereinafter cited as SPECIAL REPORT]. See McCall, Estates of Missing Persons in North Caro. lina, 44 N.C.L. REv. 275, 280 (1966).

${ }^{63}$ Colo. Rev. Stat. ANN. $\$ 153-20-3$ (1963); Iowa Code $\$ 633.584$ (1962) (temporary appointment may be made only after a hearing considering such action); N.C. GEN. StAT. \$ 28A-3 (Supp. 1965); PA. STAT. ANN. tit. 20, § 320.1202 (c) (1950); UNIFORM ABsence as Evidence of Death and Absentees' Property Act $\$ 2$ (3).

The wisdom of this type of provision is indicated by the draftsmen of the North Carohina statute: "Being an adversary proceeding . . . a certain amount of time must necessarily. elapse before the matter comes on for hearing and final determination. Without a statute similar to this one, providing for interim custody and management, the property of the missing person, which may be a going business enterprise needing immediate and constant attention, or other property which, without proper.management could suffer serious monetary loss or physical deterioration, and might lie unattended pending final determination by the Judge." SPECIAL REPORT 6. 
reasonable protection for the absentee and other interested parties. Two requirements must be met in order to sustain the propriety of a particular act by an appointee. First, there must be a statutory warrant for the act; 54 and secondly, if the power is of a type which may be exercised only with specific authorization of the court, this requisite must be complied with.

Most states authorize the appointee to take possession of the property $^{55}$ of the absentee without specific judicial authorization. ${ }^{56}$ In addition, there are provisions authorizing, without prior judicial approval, the collection of rents and income from the property and debts due the absentee. ${ }^{57}$

The statutes are less liberal in sanctioning disposition of the absentee's property or its profits, however. Many statutes explicitly require specific judicial directives for the expenditure of funds. ${ }^{.6}$

s\& For example, in In re Safris, 112 F. Supp. 146 (D.N.J. 1953), the court held that the absentee statute did not authorize the receiver to file a petition for arrangement in bankruptcy on behalf of her absentee-husband's estate.

The court may rely on its equity power to authorize what would otherwise be outside the statutory grant. In In re Parrett, 86 Ohio App. 162, 90 N.E.2d 425 (1949), an objection was raised to a trustee's application for authorization to partition and sell real estate in which the absentee held an undivided interest. The court asserted that it was unnecessary to decide whether the trustee had the right to maintain a statutory action in partition because "the nature of the action and the allegations made constitute an action for equitable partition. Equitable partition is an additional remedy to statutory partition." Id. at 164, 90 N.E.2d at 427 . The court then proceeded to rule that it could authorize the partition by virtuc of its equitable jurisdiction over the conduct of fiduciaries.

"A A material issue may be what constitutes "property" of the absentee. In Hanley v. Wadleigh, 88 N.H. 174, 186 Atl. 505 (1936), the court held that the administrator could not take property which had been held by the absentee as life tenant because the vahidity of the administrator's appointment depended upon the belief that the absentee was dead.

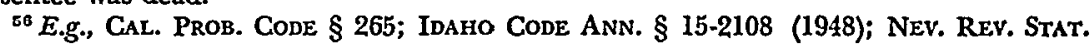
$\S 156.060$ (1959); OHio Rev. Code ANN. \$2119.03 (Page 1954).

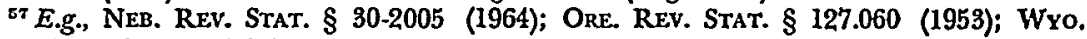
STAT. ANN. \$ 4-32 (1957).

In Esson v. Flickinger, 237 Ore. 462, 391 P.2d 769 (1964), trustces sought to justify their action in maintaining a damages suit for personal injuries suffered by the absentee prior to disappearance citing the provision which empowered them to "collect all debts, dues and credits owned by the missing person." The court rejected the argument, interpreting "debts" as being "generally associated with an obligation owed under a contract." Id. at $464,391 \mathrm{P} .2 \mathrm{~d}$ at 770 .

${ }^{88}$ E.g., Cal. Prob. Code $§ 265$ (debts); D.C. Code ANn. $\$ 20-710$ (1961) (debts, claims for alimony); OHIO REV. CODE ANN. $\$ 2119.03$ (Page 1954) (debts, insurance premiums, alimony, other obligations); WAsH. REv. CODE $\S 11.80 .040$ (1956) (care, maintenance and upkeep of the property); Wxo. STAT. ANN. § 4-32 (1959) (expenses of trust and debts). Contra, N.C. GEN. STAr. § 28A-8 (Supp. 1965) (debts, insurance premiums); Ore. REv. STAT. $\$ 127.060$ (1963) (pay expenses incident to collection of property and debts); PA. STAT. ANN. tit. 20, $\$ 320.1202$ (b) (1950) (pay premiums on life insurance). 
Moreover, a failure to obtain the requisite authorization may result in a portion of the final account being disallowed, subjecting the representative to personal loss. ${ }^{59}$ Although at least one state ${ }^{60}$ specifically authorizes the appointee to invest property at his discretion, most states require judicial sanction for any investment. ${ }^{61}$ The statutory provisions relating to the sale or encumbrance of the absentee's property are without exception in requiring judicial approval, which is often bestowed only after a hearing of which notice has been given to parties who might be affected by the action. ${ }^{62}$ Some statutes require only that the disposition be in the "best interests" of the estate and interested persons. ${ }^{63}$ Other states permit sale only for purposes of making judicially authorized payments ${ }^{64}$ and may require the personal estate to be otherwise insufficient to satisfy the obligations. ${ }^{65}$

While reasonable latitude is necessary to allow for proper administration, it is submitted that such restrictions on the disposition of the absentee's property are not necessarily undue. The purpose of the conservatorship, it should be noted, is to preserve the property until the absentee returns or is determined dead. The property will be distributed to the heirs in the latter event, and the duration of the conservatorship will in most instances be no more than seven years, ${ }^{66}$ the usual period after which death is presumed. Thus, the property is in a conceptual limbo-the rights of the absentee, while not divested, are fallow through lack of exercise and placed in question by the possibility of his death. These facts, in turn, elevate the expectations of the heirs to a level where their nascent rights arguably should be protected. In such a situation, the consent of both the potential heirs and the administering court should be required for disposition.

An important duty of the appointee in most states is to use the

\footnotetext{
${ }^{80}$ Gay v. Carlstein, 262 Mass. 551, 160 N.E. 343 (1928).

${ }^{\circ 0}$ Kx. REv. STAT. $\$ 395.420$ (2) (1960).

o1 E.g., Mass. Gen. Laws Ann. ch. 200, § 9 (1955); Minn. Stat. ANn. § 576.12 (1947);

R.I. GEN. LAwS ANN. § 33-20-5 (1956).

${ }^{62}$ E.g., Cal. Prob. Code $\$ \S 267-69$; Ore. Rev. Stat. $\$ \$ 127.080-.130$ (1963).

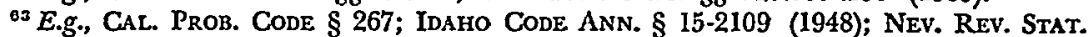
$\$ 156.090$ (1959). This determination is for the judiciary and a decision may be successfully challenged only when an abuse of discretion is shown. Estate of Scott, 181 Cal. App. 2d 605, 608, 5 Cal. Rptr. 393, 395 (Dist. Ct. App. 1960).

o E.g., Neb. Rev. Stat. \$ 30-2007 (1964); OHIo Rev. Code ANN. \$ 2119.04 (Page 1954); R.I. GEN. LAWS ANN. \$ 33-20-2 (1957).

as NED. REv. STAT. \$ 30-2007 (1964).

${ }^{\circ}$ See notes 92.94 infra and accompanying text.
} 
income of the property, or the property itself if necessary, to provide support and maintenance for those dependent on the absentee. ${ }^{67}$ The states unanimously require judicial authorization for these expenditures, and such provisions comport with the theory that not only would the absentee have been likely to support his dependents with his property, but also that the dependents have an interest in the property of their own right.

At least three states have made express provision for the continuation of a business enterprise of the absentee. ${ }^{.8}$ The most recent statute, enacted in North Carolina, typically provides that the receiver may, with the approval of the judge, "continue to operate and manage any business enterprise, farm or farming operations, and to make necessary contracts with reference thereto ...." Vital questions may be asked as to the meaning of the term "business" in these statutes. There is no indication whether it includes only such species as the sole proprietorship, or whether the term is broad enough to subsume a partnership, a wholly owned corporation or a partially owned corporation. There has been an indication that the New York statute providing for the operation of a business includes only a business which had been conducted "in individual form" and not a corporation whether wholly or partly owned by the absentee. ${ }^{70}$ The question is a pivotal one, and proper draftsmanship should insure that all businesses which are in fact dependent upon the absentee's supervision be sufficiently protected.

There are several provisions enabling the appointee to bring

o7 E.g., Conn. Gen. Stat. ANN. \$ 45-87 (1960); IdAho Code AnN. \$ 15-2109 (1948); N.C. Gen. Stat. § 28A.8 (9) (Supp. 1965); PA. Stat. ANn. tit. 20, § 320.1202 (1950) (expenditure for the support of anyone whom the absentee would be under a legal duty to support or for education of his minor children); UNIFORM ABSENCE AS EvIdence of Death and Absentees' Property Act $\$ 3(2)$.

${ }^{68}$ N.Y. SURR. Cr. ACT $\S 127$ (pending sale of business or where surrogate finds continued operation to be in best interests of the estate); N.C. GEN. STAT. \$ 28A-8 (5) (Supp. 1965); ORE. REv. STAT. \$ 127.060 (1963) (operate the property if operation is advisable).

${ }^{69}$ N.C. GEN. STAT. § 28A-8 (5) (Supp. 1965).

${ }^{70}$ In dictum, the court in In re Dix's Will, 34 Misc. 2d 421, 226 N.Y.S.2d 111 (Surr. Ct. 1962), said that "the provision refers to a business conducted by the decedent or absentee, and has no reference to any business conducted by a corporation, whether such corporation be wholly or partly owned by the decedent or absentec. The sense of the amendment is to empower the court to authorize a temporary administrator to continue the operation of any business which was conducted by the decedent or absentee in individual form." Id. at 428, 226 N.Y.S.2d at 118. The case involved a temporary administrator which had been appointed for a decedent. He was, however, acting under the same statutory authority which is vested in a temporary administrator appointed for an absentee. 
or defend suits on behalf of the absentee. The provisions may be phrased in blanket terms, presumably enabling the representative to sue or defend in all types of actions otherwise permitted by law. ${ }^{71}$ Other less sagacious statutes limit the right to a representative suit to those actions necessary to collect or protect the property of the absentee. ${ }^{72}$ A few states require specific authorization for the purpose of compromising claims and debts in behalf of or against the absentee. ${ }^{73}$ Arguably, however, the conservator should be afforded relatively great latitude in the above situations, since the statute of limitations may otherwise bar just claims of both the absentee and his creditors. Such provisions should at least allow judicial authorization for suits when necessary to protect the interests of creditors or the absentee.

The Uniform $\operatorname{Act}^{74}$ and statutes in three states ${ }^{75}$ wisely provide that courts may direct or approve the expenditure of funds by the appointee in search for the absentee. In North Carolina, the court must direct the receiver to make a search for the absentee, ${ }^{76}$ and the statute also prescribes certain minimum measures which are to be taken in the course of the inquiry. ${ }^{77}$

${ }^{71}$ E.g., Ky. REv. Stat. $\$ 395.420$ (1960) (a curator may sue and be sued); N.C. GEN. STAT. § 28A-8 (3) (Snpp. 1965) (the permanent receiver shall, under the direction of the judge, bring and defend suits); UNIFORM ABSENCE As EvIDENCE OF DEATH AND Absentees' Property ACT $\S 3(2)$ (the receiver shall, under the direction of the Court, bring and defend suits).

${ }^{72}$ E.g., N.Y. SURR. CT. AcT $\$ 127$, which allows suit for purposes of taking into possession and preserving personal property, collecting choses in action, and determining title to personal property in the representative's possession. He may be sued upon a debt or any other action which could be maintained against an administratorin-chief. See VT. STAT. ANN. tit. 14, $\$ 2308$ (1958) (suit proper to protect the property or rights of absentee).

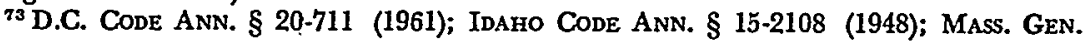
LAws ANN. ch. 200, $\$ 11$ (1955).

"Uniform Absence as Evidence of Death and Absentees' Property Act $\$ 5$.

${ }^{75}$ Colo. Rev. Stat. ANn. $\$ 153-20-7$ (1963); N.Y. Surr. CT. Act. § 131; Pa. Stat. ANN. tit. 20, $\S 320.1205(1950)$.

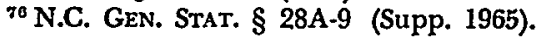

77 "The order may prescribe any methods of search deemed advisable by the judge, but must require, as a minimnm, the following:

"(I) Inquiry of persons at the absentee's home, his last known residence, the place where he was last known to have been, and other places where information would likely be obtained or where the absentee would likely have gone;

"(2) Inquiry of relatives, friends and associates of the absentee, or other persons who should be most Jikely to hear from or of him;

"(3) Insertion of a notice in one or more appropriate papers, periodicals or other news media requesting information from any person having knowledge of the $a b$ sentee's whereabouts; and

"(4) Notification of local, state and national offices which should be most likely to know or learn of the absentee's whereabouts." Ibid. 
Despite the specificity with which the appointee's powers may be delineated, no draftsman is so omniscient as to foresee all the problems of administration which may arise. To provide for such unexpected contingencies, the North Carolina act included a novel provision enabling the judge "in his discretion, by written order [to] modify, add to or subtract from the statutory powers granted ...."78 Such a provision assures that the authority granted is sufficiently flexible to cover the diverse situations which may be presented, and would clearly appear to be a desirable complement to absentee statutes.

\section{Protection for Absentee}

One source of built-in protection for the absentee is the panoply of limitations placed upon the appointee's authority to act on his behalf. As indicated earlier, specific judicial authorization must often be obtained for a particular act. ${ }^{79}$ This is especially true with respect to disbursements of the absentee's property. Also, bonds must be posted in most states, ${ }^{80}$ and may, in the court's discretion, be required in others, conditioned on the conservator's obedience to court orders and proper accounting for all property in the estate. ${ }^{81}$

In addition, many of the limitations typically imposed upon normal trustees are likewise required of the generically related conservator. For example, almost all states have provisions relating to the filing by the conservator of periodic reports with the court. ${ }^{82}$ Further, a final accounting on termination of the conservatorship or on the termination of the appointee's tenure as conservator is explicitly ordered by some states ${ }^{83}$ and would presumably be required in all cases. ${ }^{84}$ Removal of the fiduciary for adequate cause

${ }^{38}$ N.C. GEN. STAT. $\$ 25 A-8$ (Supp. 1965).

${ }^{79}$ See notes 58, 61-70, 73-78 supra and accompanying text.

80 E.g., GA. CODE ANN. $\$ 113-2703$ (1959); KY. REv. STAT. $\$ 395.410(3)$ (1960).

81 E.g., DeL. CODe ANN. tit. 12, § 4102 (1953); HawaIl REv. LAWs § 338-22 (1955); IDAHo CODE ANN. § 15-2106 (1948); R.I. GEN. LAWS ANN. \$ 33-20-4 (1956).

${ }^{82}$ In most states, the necessity and frequency of reporting is discretionary with the court. E.g., DEL. CODE ANN. tit. 12, § 4102 (1953); HAwAII REv. LAws $\$ 338-22$ (1955).

In a few states, however, reports must be submitted at designated frequencies. $E$.g., ORE. REv. STAT. $\$ 127.140$ (1963) (first Monday in April and first Monday in October of each year); WASH. REv. CODE $\S 11.80 .030$ (1956) (annually and as judge may require).

${ }^{83}$ E.g., Ohio Rev. Code ANN. $\S 2119.05$ (Page 1954); WASr. Rev. Code $§ 11.80 .060$ (1956).

ac Cf. Fidelity \& Deposit Co. v. Lindholm, 66 F.2d 56, 59 (9th Cir. 1933). 
and reappointment of another is expressly provided for in only about one-fifth of the states. ${ }^{\text {s5 }}$ However, the Massachusetts court has indicated that such power inheres in the supervisory power of equity over fiduciaries, stating in dictum that this authority is "inherent in the ... Court, and necessarily incidental to the accomplishment of the purposes of the statute...."86

\section{TERMination}

Most statutes provide for the termination of the conservatorship on the occurrence of certain enumerated events, although a few states make no such provision expressly. Commonly, the conservatorship is terminated on the return of the absentee ${ }^{87}$ or on the presentation of a power of attorney executed by the absentee and authorizing the agent so empowered to supervise the property. ${ }^{88}$ If an executor or administrator is appointed to distribute the estate of the absentee, the court will terminate the conservatorship and direct the conservator to transfer the remaining property to the personal representative. ${ }^{89}$ It is presumed that the conservatorship would also terminate if judicially authorized payments to dependents $^{90}$ should consume all of the property. Only one statute, however, expressly provides for termination on this eventuality..$^{91}$

\section{Part II. Machinery for Determination of Death aND U.TTIMATE Distribution}

Because the newly enacted North Carolina statute appears to prescribe the most novel and satisfactory plan yet devised for distributing the property of an absentee, that statute will serve as a basis for discussion in Part II. The more conventional schemes of

\footnotetext{
${ }^{80}$ E.g., ConN. Gen. Stat. ANn. \$ 45-87 (1960); Nev. Rev. Stat. \$ 156.070 (1959); Wyo. Stat. ANN. \$ 4-32 (1957).

so Webster v. Franklin County Trust Co., 313 Mass. 401, 404, 47 N.E.2d 934, 936 (1943); see note 2 supra.

s7 E.g., KY. REv. STAT. \$ 395.420 (2) (1960); NEB. REv. STAT. \$ 30-2008 (1964); NEv. REv. STAT. § 156.100 (1959).

88 E.g., R.I. Gen. Laws ANN. 33-20-10 (1956); Utah Code ANN. 75-1-11 (1953); WASH. REv. CODE 11.80 .070 (1956).

${ }^{80}$ E.g., D.C. CoDE ANN. \$20-712 (1961) (termination on the appointment of an administrator, executor, assignee in insolvency, or trustee in bankruptcy); FuA. STAT. $\S 747.04$ (1963); HawaII REv. Laws $\S 338-23$ (1955).

Because some receiverships are designed for purposes of both conservatorship and ultimate distribution, the "conservator" may himself be the party to make the final distribution. E.g., N.C. GEN. STAT. \$ 28A-13 (Supp. 1965).

${ }^{\circ}$ See note 67 supra and accompanying text.

ox ORE. Rev. STAT. $\$ 127.190$ (1963).
} 
distribution are discussed as they depart from the North Carolina plan.

\section{Presumption of Deate Versus Statute of Limitation}

A majority of states allow application for letter of administration when the absentee has been absent for the statutory or common law presumption of death period. Although in most states this period is seven years, ${ }^{02}$ the time may vary from five ${ }^{03}$ to thirty years. ${ }^{94} \mathrm{~A}$ few states, however, allow a distribution of the absentee's estate upon the lapse of a specified period of limitation. As opposed to a presumption of death, such a statute of limitation aproacl assumes neither the life nor the death of the absentee. Rather, the absentee will be barred from any interest in his property after failing to reappear for a stated time, and the fact that he later returns alive will not operate to revest his title. ${ }^{05}$ These two approaches, although often leading to similar results, rest upon divergent conceptual and operational bases, and their relative efficacy will be explored below.

The use of presumptions of death in absentee statutes has been severely criticized as an anacronism in modern law. ${ }^{98}$ Thus, Professor Wigmore has argued that the presumption does not meet the problems posed by the case of a missing person. Wigmore contends that "it uses an ancient rule-of-thumb (seven years) which

${ }^{22}$ See, e.g., AlA. Code tit. 61, § 156 (1960); DeL. CODE ANn. tit. 12, § 1701 (1953); Ohio Rev. CODE ANN. § 2121.01 (Page 1954); ORE. Rev. Stat. § 120.310 (1963); VA. CODE ANN. \$ 64-101 (1953).

${ }^{93}$ See, e.g., ARK. Stat. ANn. $\$ 62-1601$ (1947); INd. ANN. STAT. $\$ 7.2301$ (1958); VT. STAT. ANN. tit. 14, § 919 (1958).

is LA. Crv. CODE art. 70 (Slovenko 1961).

${ }^{\circ}$ See Cal. Prob. Code $\$ \S 280,284 ;$ Mass. Gen. Laws ANN. ch. 200, $\$ 13$ (1955); Minn. Stat. AnN. \$ 576.16 (1947); Neb. Rev. Stat. \$ 30-1913 (1964); N.C. Gen. Stat. $\S 28 A-11$ (c) (Supp. 1965); PA. Stat. ANN. tit. 20, § 320.1201 (1950); Wash. Rev. Code $\$ 11.80 .080-.100$ (1956).

A statute of limitations approach is not based on the state's power to administer decedents' estates but is rather justifiable as an exercise of the state's police power in the public interest. See Blinn v. Nelson, 222 U.S. 1 (1911). Several states have these statutes of limitation but, in addition, rely on the common law presumption of death. See, e.g., D.C. Code ANN. $\$ \S 14-501,20-712$ to -713 (1961); Wis. STAT. ANN. § 268.22 (1957) (interpretive commentary).

It should be noted that the Wisconsin statute preserves the common law presumption of death by omitting section one of the Uniform Act which abolished the presumption of death, UNIForm ABSENCE as Evidence of DEATH AND AusenteEs' Property AcT § 1. However, since a finding of death is no longer necessary to dis. tribute an absentee's estate, the retention of the presumption will be of little importance.

${ }^{\circ}$ See 9 Wigmore, EVIDENCE $\$ 2531$ (b) (3d ed. 1940). 
has no relation to the facts of human experience in modern conditions." 97 Furthermore, "it applies a single rule to different situations which should require different treatment." 98 There are at least four such situations in which a presumption of death may be employed: (1) when the absentee's spouse desires to remarry; (2) when an heir at law desires the distribution of the absentee's estate; (3) when a beneficiary makes claim on a life insurance policy on the life of an absentee; and (4) when the vesting of a remainder or a reversion depends upon the death of the absentee. Each of these instances have different problems and Wigmore concludes that they must be kept distinct in legislation ${ }^{99}$ in order to adequately treat the peculiar considerations involved.

It has also been argued that the common law presumption period of seven years is far too long. Conditions of communication, travel, and search have changed radically since the time of the presumption's adoption. Wigmore suggests that "the circumstances of each case should be the basis for decision, and there should be no fixed or universal rule"100 which has neither logic nor convenience to justify it.

The substance of these criticisms inveighs against a rigid application of either the presumption or the limitation approach. Wigmore's suggestions have largely been ignored, however. Only a few states besides North Carolina and those states adopting the Uniform Act ${ }^{101}$ make the determination of death for purposes of distributing an absentee's estate an issue apart from any presumption or operation of law arising from absence for a period of time. ${ }^{102}$ The

${ }^{07}$ Id. $\$ 2531$ (b), at 470-71. For example, such an arbitrary rule would not seem capable of application with equal validity to an absentee who on the one hand is a fugitive from justice and is known to have recently taken a large sum of money from his bank account and on the other to a person who was on board a ship lost at sea with no survivors having ever been found.

${ }^{93} \mathrm{Id}$. $\$ 2531$ (b), at 471 .

${ }^{o 0} \mathrm{Id}$. $\$ 2581(\mathrm{~b})$, at $471-74$.

${ }^{100} \mathrm{Id}$. $\$ 2531(\mathrm{~b})$, at 472 . (Italicized as in original.)

${ }^{101}$ Uniform Absence as Evidence of Deatr and Absentees' Property Act $\$ 8$. Although proposed in 1939, only three states have adopted the Uniform Act. MD. ANn. Code art. 16, $\$ \$ 200-12$ (1957); TENN. Code ANN. \$\$ 30-1801 to -1815 (1955); WIS. STAT. ANN. $\$ \S 268.22-.34$ (1957).

${ }^{102}$ Colo. Rev. Stat. ANN. \$ 153-20-4 (1963) (court may make a finding of death at any time during the trusteeship and judicially determine the date of death, provided the required notice is given); PA. STAT. ANN. tit. 20, $\$ 320.1201$ (1950) (court may conduct a hearing at any time after commencement of absence and upon "satisfactory evidence" may find the absentee dead and fix the date of death); TExas Pros. ConE $\S 72$ (Supp. 1965) (court authorized to grant letters of administration upon the estate of an absentee when his death shall be proved by circumstantial evidence). 
North Carolina statute ${ }^{103}$ abrogates the common law doctrine of seven years' presumption of death for the purposes of the act and superimposes an eclectic and ingenious mechanism for distribution which is designed to comport with and take cognizance of factual reality. This statute is the most recent and radical departure from traditional concepts, and will be explored at length below.

The North Carolina statute provides for three alternative decrees which terminate the receivership established for the purpose of conservation and management, ${ }^{104}$ and the act also makes provision for the distribution or return of the absentee's property. ${ }^{105}$ In order to make such a disposition effectively, this section provides for a final determination of the status of the absentee. Thus, subsection (a) prescribes that at any time during the existence of the receivership an interested party may apply for a final hearing. ${ }^{100}$ This hearing is to be conducted as would any civil suit and upon presentation of satisfactory evidence of the absentee's death, a jury, or a judge sitting without a jury, ${ }^{107}$ may make a final finding and decree that the absentee is dead. ${ }^{108}$ The transcript of the pro-

\footnotetext{
103 N.C. Gen. Stat. § 28A-1 (Supp. 1965).

${ }_{10}$ The statute provides for (1) the appointment of a permanent receiver to conserve the absentee's property, N.C. GEN. STAT. § 28A-6 (Supp. 1965); (2) the specific duties of the receiver, N.C. GEN. STAT. § 28A-8 (Supp. I965); and (3) the transfer of the absentee's property to the receiver, N.C. GEN. STAT. $\$ 28 A-7$ (Supp. 1965).

${ }_{105}$ N.C. GEN. STAT. \$ 28A-13 (Supp. 1965).

100 N.C. GEN. StAT. $\S 28 A-11$ (a) (Supp. 1965). Although the statute never specifies who is an interested party for this purpose, $\S 28 \mathrm{~A}-4$, providing for notice to interested persons, provides that notice shall be addressed to "all persons who would have an interest in the estate of such absentee if he were deceased, [and] to all persons alleged in the complaint to claim an interest in the absentee's property ...." N.C. Gen. Stat. § 28A.4 (Supp. 1965). Similarly, § 28A-2(c), specifying who are to be parties to an action for a receiver, provides that "all persons who would have an interest in the estate of such absentee if he were deceased, all persons known to claim an interest in the absentee's property, and all known insurers of the life of the absentee shall be made parties to the action." N.C. GeN. STAT. $\$ 28 A-2$ (c) (Supp. 1965).

${ }_{107}$ The filing of an application for a final hearing by an interested party is in effect a motion that the case be docketed for trial on the issue of the absentec's status. This issue is to be determined as would an issue of fact in any civil case. Therefore, under N.C. GEN. STAT. $\S 1-172$ (1953), the issue must be tried by a jury unless a trial by jury is waived at which time the issue will be triable to the judge. ${ }^{108}$ Subsection (b) of $\S 28 \mathrm{~A}-1$ provides that in determining the fact of death upon the evidence, exposure to a "specific peril of death" is to be explicitly considered by the judge and, if there is a jury, it shall be sufficient evidence to submit the issue to the jury. N.C. GeN. STAT. \$ 28A-I (b) (Supp. 1965). It must be noted that this is not an exclusive rule and a determination of death may arise under circumstanccs inconsistent with life even though there is no showing of exposure to specific peril.

Upon the entry of such a final finding, $\S 28 \mathrm{~A}-12$ (1) provides that the judge shall wind up the receivership and terminate the proceedings by: (I) "satisfying all out-
} 
ceedings will then be certified to the Clerk of the Superior Court, who administers the estate of the absentee as that of a decedent. ${ }^{100}$ If the court or jury determines that sufficient evidence of death has not been presented, the receivership merely continues.

Provision is likewise made for termination and distribution in the event that the absentee should reappear or his presence becomes known. Subsection (b) provides that at any time during the receivership any party in interest may apply to the judge for a finding that the absentee is still alive.110 After hearing the evidence, the court may find as a matter of fact that the absentee is living and return his property to him.111

Subsection (c) provides for the ultimate termination of the receivership even though there has been no finding of either the death or continued existence of the absentee. ${ }^{112}$ After a lapse of five years, ${ }^{113}$ the judge may call for a final hearing and take evidence as to whether or not the absentee should be barred from any interest in his property because of his failure to appear. ${ }^{114}$ Subsection (c) is

standing expenses and costs of the receivership"; (2) deducting a stated percentage for the absentee insurance fund, N.C. GEN. STAT. \$28A-12 (1) (Supp. 1965); (3) requiring the receiver's account, discharging him and his bondsman upon approval thereof, and entering a final decree of termination, N.C. GEN. STAT. $\$ 28 A-12$ (4) (Supp. 1965).

${ }_{109}$ N.C. GeN. Stat. \$ 28A-11 (a) (Supp. 1965).

110 N.C. GEN. STAT. § 28A-11 (b) (Supp. 1965).

111 When there is such a revocation of the finding that the missing person is an absentee, $\S 28 \mathrm{~A}-12$ (2) provides that the judge shall terminate the proceedings by: (I) "satisfying all outstanding expenses and costs of the receivership"; (2) returning the remaining property to the absentee and rendering an accounting for the property not returned, N.C. GEN. STAT. \$ 28A-12(2) (Supp. 1965); and (3) requiring the receiver's final account discharging him and his bondsman, and entering a final decree of termination, N.C. GEN. STAT. \$ 28A-12 (4) (Supp. 1965).

112 N.C. GeN. Stat. § 28A-11 (c) (Supp. 1965).

${ }^{113}$ Section 28A-14 provides for an alternative period of limitation. If at the time a receiver is appointed it is found that the absentee has been missing for four years, the period of limitation "shall be not less than two years after the date of the appointment of the permanent receiver instead of the five years . . ." N.C. GEN. STAT. \$ 28A-14 (Supp. 1965).

Some of the states basing distribution on a statute of limitation have similar provisions, presumably to furnish the most expeditious and equitable settlement possible. See, e.g., Mass. Gen. LAws ANn. ch. 200, § 13 (1955); Minn. Stat. AnN. § 576.16 (1947).

114 "[T] he judge may [then] decree that the absentee has lost all interest in his property and that the right to such property has devolved upon others by reason of his failure to appear." SPEcial REPORT 15.

It would seem that the statute is deficient in this respect, for there is no indication as to the nature or significance of the further evidence to be taken. Likewise, there is no indication as to whether the judge must call for a final hearing. If he chooses to stay a final hearing or, upon hearing, refuses to decree that the absentee 
clearly a statute of limitation, based on the police power of the state and assuming neither the life nor the death of the absentee.115 The validity and efficacy of such a provision are apparent. As to the former, the Supreme Court in Blinn v. Nelson ${ }^{110}$ recognized the constitutional power of a state to provide by legislation for the preservation of an absentee's estate for a reasonable time and to designate a period of limitation at the expiration of which he must appear or lose all interest in his property.117 Further, it is arguable that on policy grounds a statute of limitation which bars one's claim to his property when it is not asserted within a reasonable time is not unfair. It is generally understood that one is subject to the loss of his property through failure to pay the taxes assessed upon it or by virtue of its adverse possession for a specified period of time. Missing persons are at least as debilitating to the stability of title as are such ascertainable claimants and if they neglect to safeguard their own property, they should have no right to have it protected indefinitely or until they decide to return. ${ }^{118}$

Similarly, the North Carolina provision appears to have met the objections interposed against a rigid application of a presumption

will be barred, the conservatorship could presumably remain in operation indefinitely. See 1942 WIs. L. REv. 280, 282.

Following a decree of devolution, the judge is to terminate the proceedings under \$ 28A-12 (3) by: (1) "satisfying all outstanding expenses and costs of the receivership"; (2) "satisfying all outstanding taxes, other debts, and charges"; (3) deducting for the absentee insurance fund; (4) transferring and distributing the remaining property, N.C. GEN. STAT. \& 28A-12 (3) (Supp. 1965); and (5) requiring an accounting from and upon approval thereof, discharging the receiver, N.C. GEN. STAT. \$ 28A-12 (4) (Supp. 1965). Section 28A-15 specifically provides that an absentee cannot bring an action for the recovery of his property after a final finding or decree has been made, although he may be reimbursed under an insurance provision included in the statutc. N.C. GeN. Stat. § 28A-15 (Supp. 1965). See notes 179-86 infra and accompanying text.

${ }^{115}$ See note 95 supra and accompanying text.

${ }^{210} 222$ U.S. 1 (1911).

${ }^{117}$ Id. at 7. The Blinn case involved a Massachusetts statute which provided that if the absentee did not appear to claim the property within fourteen years after the appointment of a receiver, his title would be barred. Also, if the receiver is not appointed within thirteen years from the date of disappearancc, the time for distribution and barring actions will be one year after the appointment of the receiver instead of fourteen years. Id. at 2. The question posed to the Court was whether a statute of limitations that might possibly run for only one year was invalid. The Court asserted that "if the legislature thinks that a year is long enough to allow a party to recover his property from a third hand, and establishes that time in cases where he has not been heard of for fourteen years and presumably is dead it acts within its constitutional discretion. ... [I]n the great majority of instances no doubt justice will be done." Id. at 7 . See also Beckwith v. Bates, 228 Mich. 400, 200 N.W. I5I (1924).

${ }^{118}$ American Land Co. v. Zeiss, 219 U.S. 47, 62 (1911). See Lees, Property Rights of Persons Who Have Disappeared, 9 MinN. L. Rev. 89, 99 (1925). 
or limitation-type statute. It would appear that criticism of a presumption of death period is valid only when leveled at a naked presumption unaccompanied by a provision for the binding factual determination of death before the presumptive period has run. ${ }^{119}$ Although application of a presumption in all cases would often lead to arbitrary and unjust results, instances will arise when neither death nor continued life can be shown or even said to have the greater probability. In such instances the presumption serves a useful purpose, for it will be necessary to distribute the estate at some time in the future and this will necessarily be an arbitrary date. The length of time chosen as a waiting period before distribution, rather than the form of the provision, will to a great extent determine its ability to meet such problems. In terms of practical result, there is no distinction between constructing this period in the form of a five-year presumption of death and doing so in the form of a five-year statute of limitations. The real difference between the more enlightened modern legislation and the old presumption of death statutes is the supplementary provisions employed in the former. It would seem that in the modern statutes both the presumption of death and the statute of limitations are theoretically predicated upon the reasoning that property has been abandoned and it is promotive of the general welfare of society and certain third parties that this property be finally distributed. Either form purports to be binding on the absentee, and if they provide for an earlier determination of death and yet are constitutional because they have made provision for protection of the absentee's interests, have given him notice and afforded a reasonable period of time in which to return and claim his property, ${ }^{120}$ they are of equal sufficiency in dealing with the problems involved.

The most serious fault to be found in the use of a statute of limitations for the distribution of an absentee's property is that since death is not in issue, the date of death will not be dispositively determined. However, under all absentee statutes, the date by reference to which heirs, next of kin or insurance beneficiaries are to be determined is pivotal to a distribution to the proper parties. The Uniform Act failed to meet this problem when it provided that distribution is to be made as of the date determined by the

\footnotetext{
120 See N.C. GeN. Star. § 28A-11 (a) (Supp. 1965).

- ${ }^{120}$ See Cunnius v. Reading School Dist., 198 U.S. 458, 476-77 (1905).
} 
court in its final finding, ${ }^{121}$ for there is no indication of what criteria are to be used in fixing such a date in the event that the final finding is not based upon a factual determination of death. ${ }^{122}$ The North Carolina act remedies this situation by specifically providing that the absentee's estate is to be distributed "as though ... [he] died ... on the day five years after the date of his disappearance ...."123 It is to be noted that this provision does not fix the time of death, but it does solve the problem of identifying the correct distribution date by simply providing a point in time with reference to which all rights are to be determined. Surprisingly, statutes based on a presumption of death are no more successful in escaping the date-of-death problem. Although death is an issue under such a statute, the majority rule is that the presumption relates only to the fact of death and not to the time of death. ${ }^{124}$ While courts adhering to the majority rule will allow the submission of evidence which tends to show that the date of death in fact occurred before the expiration of the presumptive period, ${ }^{125}$ the problem of determining the distributees remains if the requisite evidence cannot be found. At least three presumption of death statutes have attempted to solve this problem with provisions fixing an actual date of death. ${ }^{126}$

\section{Requirements of Due Process}

(I) Reasonable period of time

Cunnius v. Reading School Dist., ${ }^{127}$ in upholding the states' power to pass special absentee statutes as within the permissible

121 Uniform Absence as Evidence of Deati and Absentees' Property Act \$ 9.

${ }^{122}$ See 1942 Wis. L. REv. 280, 282.

${ }^{123}$ N.C. GEN. STAT. \$ 28A-13 (Supp. 1965).

124 See Mutual Life Ins. Co. v. Hamilton, 143 F.2d 726 (5th Cir. 1944); Griffin v. Northwestern Mutual Life Ins. Co., 250 Mich. 185, 229 N.W. 509 (1930); Heffort v. Metropolitan Life Ins. Co., 173 Ore. 353, 144 P.2d 695 (1944); 9 Wigmore, Evidence $\$ 2531$ (a) (3d ed. 1940); 38 Colum. L. Rev. 322, 325 (1938); 3 RutGers L. Rev. 266, 268 (1949).

A minority of the states hold that the passing of a specified period of time raises a presumption which both fixes the fact of death and the time of death at the end of the period. See In re Chicago \& N.W. Ry. Co., 138 F.2d 753 (7th Gir. 1943); Thompson v. Pamet, 82 Ohio App. 366, 78 N.E.2d 419 (1948); 9 Wigmore, Evidence § 2531 (a) (3d ed. 1940); 3 RuTGERs L. Rev. 266, 268 (1949).

125 See cases cited note 124 supra.

${ }^{126}$ IND. ANN. STAT. \$ 7-2302 (1953) (presumed to have died on the first day of his disappearance); Mich. STAT. ANN. $\$ 27.3178$ (335) (1962) (presumed to have died seven years from the date of his disappearance); PA. STAT. ANN. tit. 20, $\$ 320.1201$ (b) (1950) (presumed to have died seven years from the time last heard of).

${ }_{127} 198$ U.S. 458 (1905). See notes 8.11 supra and accompanying text. In this case 
ambit of the due process clause, asserted that such statutes must afford the absentee a reasonable length of time after an action to divest him of title has been brought in which to return and claim his property. ${ }^{128}$ In Jight of the modern methods of transportation, communication and search, and taking note of the periods deemed reasonable in other states, ${ }^{129}$ the five-year period in North Carolina $\mathrm{1}^{\mathbf{1 3 0}}$ would appear to be sufficient although by necessity arbitrary. It must be noted that the factual finding of death under section 28A-11 (a), contrary to the statute of limitation contained in section $28 \mathrm{~A}-11$ (c), may be made at any time during the receivership, and yet both sections are equally binding on the absentee. It is questionable whether a reasonable time has been insured the absentee in the former circumstance should he in fact be alive and return. ${ }^{131}$

the defendant assumed a debt owed to the plaintiff. The plaintiff then disappeared and was missing for a year. Under the applicable seven-year presumption of death statute in force in Pennsylvania, plaintiff's son applied for and was granted letters of administration on his father's estate. Pursuant to his duties the administrator collected interest on the debt from defendant and gave him a receipt and discharge in return. The plaintiff then returned and sued defendant for the same interest. Id. at 460-61. The court held that the state could constitutionally enact the statute in question in the exercise of its police power. However, the court placed limitations on this power by conceding that if the statute were "an arbitrary and unreasonable presumption of death resulting from absence for a brief period,... did not provide adequate notice as prerequisite to the proceedings for the administration of the estate ... [and] contained no adequate safeguards concerning property ..." the statute would be repuguant to the fourteenth amendment. Id. at 476-77.

${ }^{128}$ Id. at 477 . The Court did not attempt to define what period would afford the absentee a reasonable length of time in which to return and claim his property. The statute in question employed a seven-year presumption of death. As to this period of time the Court noted that "it certainly cannot be said to be unreasonable." Ibid.

${ }^{120}$ See, e.g., CONN. GEN. STAt. ANN. \$ 45-199 (1960) (five-year period); IND. ANN. Stat. § 7-2306 (1953) (three-year period); Mick. Stat. AnN. § 27.3178 (395) (1962) (three-year period); ORE. REv. STAT. \$ 120.370 (1963) (five-year period). See also Blinn v. Nelson, where it was held that the legislature of Massachusetts acted within its constitutional discretion when it provided that the absentee had one year in which to appear and recover his property when he had been missing for thirteen years before a receiver was appointed.

130 N.C. Gen. Stat. § 28A-11 (c) (Supp. 1965).

131 Under the provisions of N.C. GEN. STAT. \$ 28A-2 (Supp. 1965), a temporary receiver may be appointed thirty days after the absentee's disappearance. N.C. GEN. STAT. $\$ 28 \mathrm{~A}-3$ (Supp. 1965) requires that within thirty days of his appointment, the temporary receiver shall file an inventory of all the property he has taken in charge. Further, N.C. GEN. STAT. § 28A-4 (Supp. 1965) provides that upon the filing of this inventory, notice shall be sent to interested persons of the hearing for a permanent receiver. The return day of the notice may be as few as thirty days and no more than sixty days subsequent to its issuance. When notice is returned, a permanent receivership may be established and at any time subsequent to its establishment, a determination of death may be rendered. It is thus conceivable that the absentee could be declared dead and barred from all his property rights under N.C. GEN. STAT. \$ 28A-15 (Supp. 1965) after the period of ninety days. 
(2) Notice

Cunnius also requires that the statute "provide adequate notice as prerequisite to the proceedings for the administration of the estate of an absentee."132 It is unfortunate that the Court did not specify in detail what would be considered "adequate" notice. Publication of notice is usually provided for in the statutes, ${ }^{133}$ and such notice prefatory to distribution was deemed reasonable by the Cunnius Court. ${ }^{134}$ Many states require notice to be directed to the absentee to show satisfactory evidence of his continued life. ${ }^{135}$ It is significant that under the North Carolina statute, notice need only be given before the hearing for appointment of a permanent receiver ${ }^{136}$ and need not be given again at the time of the final finding and decree, ${ }^{137}$ or the point at which the absentee's property rights are finally and irrevocably barred. ${ }^{138}$ It is believed that, if tested, the statute would be held constitutional in light of Blinn $v$. Nelson, which did not appear to base the validity of the absentee statute in question on the presence of technical publication notice which will give little practical protection. The question framed there was simply whether the procedure followed was fair and reasonably appropriate to cope with a problem within the proper scope of state legislation. .39 $^{139}$

152198 U.S. at 477 .

${ }^{133}$ See Committee on Administration of Property of Infants, Incompetents and Missing Persons, Report, 102 Trusts \& Estates 908 (1963).

134198 U.S. at 176.77 .

${ }^{135}$ See, e.g., ALA. CoDE tit. 61, $\S 159$ (1960) ("said notice shall require the sup. posed decedent, if alive, or any person for him, to produce ... satisfactory evidence of his continuance in life"); D.C. CODE ANN. $\$ 20-703$ (1961) ("the court may issue a notice... which shall be addressed to such absentee and to all persons who claim of record an interest in said property ... . citing them to appear . . . and show cause why a receiver ... should not be appointed ..."); GA. CODE ANN. § 113-2603 (1959) ("said notice shall require the supposed decedent, if alive, or any person for him, to produce ... satisfactory evidence of his continuance in life").

${ }^{138}$ N.C. GeN. STAT. § 28A-4 to -5 (Supp. 1965).

137 N.C. GeN. STAT. § 28A-11 (Supp. 1965).

${ }^{138}$ See American Land Co. v. Zeiss, 219 U.S. 47, 63 (1911); Mullane v. Central Hanover Bank \& Trust Co., 339 U.S. 306, 317 (1950) (dictum).

N.C. GEN. STAT. $\$ 28 A-4$ (Supp. 1965) provides that notice prior to establishment of receivership shall issue addressed to the absentee, to all persons who would have an interest in his property, and to all whom it may concern. The statute further provides that the absentee shall be served by publication for four weeks in a newspaper in the county where the proceeding is pending, shall be sent notice by registered or certified mail to his last known address, and shall have notice posted on each parcel of land subject to the proceedings. N.C. GEN. STAT. $\$ 28 A-5$ (Supp. 1965).

${ }^{130} 1942$ WIS. L. REv. 280, 290.

Although there is no express language to this effect, this interpretation is cer. tainly to be inferred from the Court's decision. After establishing that the pro- 
(3) Protection of the absentee

The states have also devised various procedures in an effort to meet the third requirement called for by Cunnius v. Reading School Dist., protection of the absentee's interest should he in fact be alive. ${ }^{140}$ Some have seen fit to provide for the absentee's recovery of his estate if he should return at any time in the future. ${ }^{141}$ At the other end of the spectrum, several states provide for the tolling of a statute of limitations at the end of which time the property is distributed and the absentee is barred from any claim to his estate..$^{142}$ A number of states provide a period of time, usually twelve weeks, ${ }^{143}$ between the presentation of evidence sufficient to satisfy a presumption of death and the granting of letters of administration, within which time evidence of continued life must be presented to prevent distribution. ${ }^{144}$ Another common provision is one which allows provisional distribution or provides for a holding period at the time letters are granted with final distribution being made after the passing of a given period of time. ${ }^{145}$

Regardless of when distribution of the absentee's estate is made, courts in some states require the distributees to furnish a secured bond conditioned on their refunding the property or its value if the absentee should return or if he is later proved to have been alive at the time of distribution. ${ }^{148}$ The bond may have perpetual valid-

visions in question were within the scope of a proper state function, the Court said that "there is reasonably careful provision for notice by publication before the appointment [of a receiver] and the whole proceeding begins with a seizure by the sheriff of the property mentioned in the original petition." 222 U.S. at 6-7. (Emphasis added.) See 1942 WIs. L. REv. 280, 289-90.

140198 U.S. at 477.

${ }^{141}$ See, e.g., Ark. Stat. ANn. \$ 62-2122 (c) (Supp. 1965) (if the "alleged decedent is not dead, he may ... at any time recover the estate . . ."); MIss. Cone ANN. $\$ 1698$ (1956) ("but any property or estate recovered in any such case shall be restored to the person evicted or deprived thereof, if, in a subsequent action, it shall be proved that the person so presumed to be dead is living").

${ }^{142}$ See, e.g., Mass. Gen. Laws ANn. ch. 200, § 12 (1955); Minn. Stat. ANn. \$ 576.15 (1947); N.C. GEN. STAT. $§ 28 A-15$ (Supp. 1965). The Massachusetts provision was held constitutional in Blinn $v$. Nelson, it being a statute of limitation which the Court found reasonable.

${ }^{145}$ FLA. STAT. $\$ 734.35$ (1963) (absentee is given three months in which to show evidence of continued life); GA. CODE ANN. \$ 113-2603 (1959) (same).

14' See, e.g., Ara. Cone tit. 61, \$ 160 (1960); OHIo Rev. Cone ANN. $\$ 2121.04$ (Page 1954); VA. CoDE ANN. \$64-106 (1950).

${ }^{145}$ See, e.g., Colo. REv. STAT. ANN. \$ 158-20-6 (4) (three years); Mich. Comp. LAws $\S 705.10$ (1948) (one year if bond posted, three years if no bond is posted); N.H. REv. STAT. ANN. § 553:18 (1955) (five years).

${ }^{140}$ See, e.g., IND. ANN. STAT. \$ 7-2306 (1953); ORE. Rev. Stat. \$ 120.370 (1963); W. VA. CODE ANN. $\$ 4243$ (1961).

It is generally provided that if the distributee cannot provide security, his share 
ity $^{147}$ or it may be cancelled and the absentee barred at the end of a period of time varying from three ${ }^{148}$ to thirty years. ${ }^{140}$

The rights of an absentee who returns before being barred from claim to his estate are not uniform. He may be allowed to do one or more of the following: recover all undistributed property, ${ }^{150}$ recover distributed property, ${ }^{151}$ receive the profits from his estate with interest accrued during the time his estate was held by distributees, ${ }^{152}$ require an accounting, ${ }^{153}$ be substituted as a party in pending actions, and reopen judgments rendered against the administrator of his estate. ${ }^{154}$

It has been suggested that the most satisfactory solution to the problem of administering the estate of an absentee is to make ultimate distribution the last act in a receivership proceeding initiated for the preservation of the estate and the support of dependents. ${ }^{165}$ By allowing the statute of limitations to run contemporaneously with and terminate simultaneously with the receivership, North Carolina and other states ${ }^{156}$ have avoided the problems and complications incident to the necessity of requiring provisional distribution, holding periods and bond. Further, these states have successfully met the due process requirements of reasonable time and adequate protection of the absentee's interests.

The North Carolina statute ${ }^{157}$ provides an additional, novel and effective approach to the problem of protection of the absentee. The statute authorizes the creation of an insurance fund to be financed by the deduction of five per cent of the absentee's estate ${ }^{168}$

of the estate will be transferred to a trustee who will invest the property and pay over the earnings to him until such time as security can be given or the bond would have been cancelled if it had been given at the time of distribution. Sce, e.g., Conn. Gen. Stat. AnN. § 45-199 (1960); Del. Code Ann. tit. 12, § 1708 (1953).

${ }^{14 \tau}$ See, e.g., Mo. ANN. Stat. \$ 473.713 (1956); OHo REv. Code ANN. § 2121.08 (Page 1954); Pa. Stat. ANN. tit. 20, § 320.1203 (1950).

${ }_{148}$ NEv. REv. STAT. \$ 156.220 (1959).

149 LA. Crv. CODE arts. 65, 68 (Slovenko 1961).

${ }^{150}$ See, e.g., Cal. Prob. Code § 271.

${ }^{181}$ See, e.g., Ala. Code tit. 61, § 161 (1960); Cozo. REv. Stat. ANN. $§ 158-20-6$ (4)

(1963) (recovery except from good faith purchaser for valuc).

${ }^{152}$ See, e.g., ArIz. Rev. Stat. ANN. \$ $12-509$ (1956).

${ }^{163}$ See, e.g., D.C. Code ANN. \$ 20-712 (1961); NEB. REv. STAT. \$ 30-2008 (1964).

${ }^{154}$ See, e.g., ORE. REv. STAT. \$ 120.390 (1963); VA. COdE ANN. \$ 64-110 (1950).

${ }^{158}$ Sce Legislation, 43 Harv. L. REv. 485, 488 (1930); 2 INTRAMural L. REv. 107, 111 (1947).

${ }^{15 B}$ See statutes cited note 101 supra.

157 N.C. GeN. Stat. § 28A-19 (Supp. 1965).

${ }^{158}$ It is provided that the five per cent shall be deducted from "the total value of the property remaining for distribution upon settlement of the absentee's estate, 
at the time of distribution and the depositing of such amount with the state treasurer to be invested and retained. If at any time the absentee should return and appear personally before the treasurer, the jurisdiction of the Superior Court may be invoked to order payment to him of an amount from the fund which the court finds is fair and reasonable under the circumstances. ${ }^{159}$ In making such a determination, the court is to take into account "the disposition made of his property, the reasons for his absence and other relevant factors."'160

An absentee insurance fund has several significant advantages over the more common requirements of provisional distribution with posted security. Should the absentee return at any time, he is assured of some compensation from the insurance fund, whereas under most bond provisions his entire claim will eventually be barred. Such a fund obviates the difficulty that a distributee may encounter in providing and securing a bond and, additionally, protects the distributee from a possible loss of the property he has received. ${ }^{161}$ Because the absentee receives only the amount that the court chooses to tender him and not the entire value of his estate, there is a very limited inducement to fraud in such a provision. ${ }^{162}$ Furthermore, it would appear that the deduction from the absentee's estate would be so insignificant in most cases that it would result in little discomfort to the distributees. ${ }^{163}$

Only those states adopting the Uniform Absence as Evidence of Death and Absentee' Property Act ${ }^{164}$ have similar absentee in-

including amounts paid to the estate from policies of insurance on the absentee's life ...." N.C. Gen. Stat. § 28A-12(1), (3) (Supp. 1965).

${ }^{200}$ This action must be brought within three years after the absentee's return. In the case of "infancy or other disability recognized by law," the action must be begnn within one year from the removal of the disability. N.C. GEN. STAT. \$ 28A-19 (d) (Supp. 1965).

${ }_{100}$ N.C. GEN. STAT. \$ 28A-19 (c) (Supp. 1965).

${ }^{101}$ See Legislation, 38 ColUM. L. REv. 322, 335 \& n.69 (1938).

${ }^{102}$ If the returning absentee were allowed to recover the full value of lis estate instead of being limited to the amount the court chooses to give him, "simply by disappearing for a number of years, a person, in collusion with his heirs, could secure both the distribution of his property to them, and its money value for himself." Id. at 335 .

${ }^{103}$ Bohrer, Life, Disappearance and Death, 39 CHr. B. Rec. 199, 204 (1958).

It should be noted that Tennessee, one of the few states having an insurance provision, has provided that twenty-five per cent of the total value of the absentee's property remaining, including amounts obtained from life insurance policies, is to be deducted for the insurance fund. TENN. CODE ANN. \$ 30-1810 (1955). Rather than being insignificant, this amount would seem quite substantial.

106 Uniform Absence as Evidence of Death and Absentees' Property Acr $\$ 11$. 
surance provisions. ${ }^{105}$ However, the North Carolina act has made several significant additions to the Uniform Act. First, it provides for insurance fund protection established at the time when the property has been distributed, irrespective of whether the distribution was based on a finding of death based on circumstantial evidence or a finding of unexplained absence for five years. ${ }^{100}$ The Uniform Act insurance fund, on the other hand, only provides protection in the latter situation. ${ }^{107}$ Constitutional questions aside, ${ }^{108}$ it would appear that an absentee should never be completely barred from all recovery. The danger that his estate will be maladministered and the possibility that he will eventually return are both foreseeable contingencies however clear the circumstantial evidence may be. ${ }^{160}$

The North Carolina act also diverges from similar insurance schemes in that it allows the treasurer to change the rate to be charged for the insurance fund "from time to time" on the basis of actuarial experience. ${ }^{170}$ The Uniform Act contains no such provision. ${ }^{171}$ It has been suggested that an insurance fund could be utilized most effectively if it contained a rate schedule contingent upon such factors as the circumstances of the disappearance, the

${ }^{105}$ MD. ANN. Code art. 16, § 210 (1957); TENN. Code ANN. $\$ 30-1810$ (1955); Wis. Stat. ANN. § 268.31 (1957), as amended, Wis. Stat. ANN. § 268.31 (Supp. 1966).

200 N.C. GEN. STAT. \$ 28A-12 (1) (b), (3) (c) (Supp. 1965).

187 Uniform Absence as Evidence of Death and Absentees' Property Act § 8 (2) (b).

"In each case of termination of receivership as provided in Section 8 , the Court, except in cases where the proceedings have been certified to the probate Court under Subdivision 1, Section 6 [a finding of death], shall set aside the sum there named and direct its payment by the receiver, to the [treasurer] of the State." UNIFORM ABSENCE AS Evtoence of Death and Absentees' Property Act $\$ 11$ (1).

${ }^{108} \mathrm{It}$ is arguable that in cases where there are circumstances justifying a finding that the absentee is dead, protective measures may be constitutionally dispensed with. If proof of death had been made by direct evidence, no protective measure would have been required and, since a fact may be established by circumstantial evidence as well, no protective measure should be required in the latter instance. See Jackson v. Richardson, 182 Ark. 997, 1003, 33 S.W.2d 1095, 1097-98 (1930).

${ }^{100}$ Bohrer, supra note 148, at 204.

170 N.C. GEN. STAT. $\$ 28 A-19$ (e) (Supp. 1965).

The Maryland fund did not state a fixed percentage to be initially applied, but rather provided that the "Treasurer shall, from time to time, prescribe the rate to be charged for the insurance fund on the basis of actuarial experience." MD. ANN. CoDE art. $16, \S 210$ (4) (1957).

${ }^{171}$ While not allowing the treasurer to change the rate to be charged an estate, the Uniform Act does provide that if the "accumulated fund increases to an amount actuarily found to be in excess of reasonable requirements" the court may authorize the treasurer to reduce it by transferring part of the fund to the general fund of the State Treasury. Uniform Absence as Evidence of Death and Absentegs' Property Act $\S 11(4)$. 
age of the absentee and his state of health. ${ }^{172}$ While North Carolina's flexible rate provision could be advantageously amended to provide for such contingencies, it is certainly a commendable advance in the direction of greater efficacy in use of the insurance fund.

\section{Insurance as an Asset of the Absentee's Estate}

Only a few states have enacted special provisions designed to cover those situations where life insurance is an asset of the missing person's estate. ${ }^{173}$ The North Carolina act authorizes the judge at the time of a distribution to order payment of the proceeds of any life insurance policy on the life of the absentee, based on the fiveyear absence of the insured. Such distribution is to be made "to the proper parties as their interest may appear."174 In the event that the insurer refuses to make payment under these circumstances; the judge is authorized to determine all issues arising under supplemental pleadings then filed, provided that issues of fact are to be tried by a jury. ${ }^{175}$ If the insured's death is established in such a proceeding, ${ }^{176}$ the proceeds of the policy shall be paid forthwith. However, if such death cannot be factually proved, the judge may

172 Bohrer, supra note 148 , at 204.

${ }^{173}$ Colo. Rev. Stat. ANN. § 153-20-9 (1963); MD. ANN. Code art. 16, § 209 (1957); N.C. Gen. Stat. § 28A-18(a) (Supp. 1965); TENN. CODE ANN. \$ 30-1812 (1955); Wis. STAT. ANN. $\$ 268.30$ (1957).

Indiana provides that one holding or entitled to the proceeds of any life insurance policy on the life of an absentee need only prove death for these purposes by showing five years absence, provided that such proof is not prohibited by the contract. IND. ANN. STAT. \$ 7-2302 (1953).

174 N.C. GeN. Stat. § 28A-18 (a) (Supp. 1965).

It should be noted that this section does not refer to a distribution of the absentee's estate based on a finding of death under $\$ 28 \mathrm{~A}-11$ (a). Presumably, the insurer's obligation to pay over the proceeds of the policy under these circumstances would be unquestionable.

178 N.C. GEN. STAT. \$ 28A-18 (b) (Supp. 1965).

${ }^{170}$ Section $28 \mathrm{~A}-18(\mathrm{~b})$ does not specify the nature or amount of evidence necessary to make a finding of death. However, it would seem that $\S 28 \mathrm{~A}-1$ should be read together with $\S 28 \mathrm{~A}-18(\mathrm{~b})$ as indicating the standard of proof in this instance. The former section provides that "in any action under this chapter, where the death of a person .... is in issue the fact that he has been absent from his place of residence, unheard of for seven years, or for any other period, creates no presumption requiring the judge or the jury to find that he is now deceased. The issue shall be decided by the judge or jury as one of fact upon the evidence." N.C. GEN. STAT. § 28A-1 (Supp. 1965). (Emphasis added.) Presumably this encompasses circumstantial as well as direct evidence of death. Section 28A-1 (b) provides that "if during such absence the person has been exposed to a specific peril of death, this fact shall be considered by the judge; or if there be a jury, shall be sufficient evidence to be submitted to the jury." N.C. Gen. Stat. § 28A-1 (b) (Supp. 1965). 
not order the policy paid. ${ }^{177}$ The policy does not remain extant and unenforceable in this event, however. "The fact remains that the insured has disappeared and his whereabouts [are] unknown for more than 5 years and that under the terms of ... [ the North Carolina act] his property is distributable as though he were dead."178 Therefore, the act provides that the receiver may demand the payment of the cash surrender value or obtain a loan on the policy. The receiver's receipt for such payment will release the insurer from all claims under the policy. ${ }^{179}$

It is to be noted that the North Carolina statute also provides that if the beneficiary's survival of the absentee is "not established" and the insured absentee owns an interest in the policy, the proceeds of the insurance will be considered part of the absentee's estate and will be distributed under the regular provisions of the act. 180 . Since distribution under a statute of limitations act presupposes an inability to establish the fact of death, it is not clear to what point in time the beneficiary must survive in the instance where the insurance company does not object to payment on the policy at the end of five years absence or where the surrender value is paid at this time. In such event, the policy is to be paid to "the proper parties as their interests may appear," 181 and to qualify as a proper party a beneficiary must survive the absentee. The referent cannot be the time of the insured's death because the fact of death has not been at issue in the proceedings. The only logical alternative is the beneficiary's survival of the five-year period of limitation..$^{182}$ It is suggested that this point in time should be made more definite. ${ }^{183}$

North Carolina appears to have avoided many of the problems that may arise with respect to life insurance. By providing for an action to "determine all issues arising upon the pleadings" when

\footnotetext{
${ }^{177}$ Since the insurer's liahility is conditioned upon the death of the insured, to order full payment of an insurance policy without establishing death would arguably be an impairment of the obligation of the contract and repugnant to article $\mathrm{I}, \S 10$ of the United States Constitution.

${ }^{178}$ SPEEctal RePORT 23. (Emphasis added.)

${ }^{270}$ N.C. Gen. StAT. \& 28A-18 (d) (Supp. 1965).

180 N.C. GEN. STAT. $\$ 28 A-18$ (c) (Supp. 1965).

${ }^{282}$ N.C. GEN. STAT. $\$ 28 \mathrm{~A}-18$ (a) (Supp. 1965). See text accompanying note 174 supra.

${ }_{282}$ N.C. Gen. STAT. § 28A-1l (c) (Supp. 1965).

${ }^{288}$ See 1942 WIs. L. REv. 280, 287.
} 
the insurance company refuses to make payment on the policy, ${ }^{184}$ it is assumed that there will be a resolution of the time when death has occurred as well as the factual determination of death. The former would be important if it were contended that the period of time within which action upon the policy must be brought has passed, ${ }^{185}$ that the policy has lapsed through failure to pay premiums, ${ }^{186}$ or that the beneficiary has failed to survive the insured.

\section{CONCLUSION}

The problems which may be occasioned by the disappearance of a person can best be handled by statutes which provide for the expeditious creation of a flexible conservatorship and for distribution of the absentee's property at a time dictated by the realities of the particular situation. The conservator should have sufficient authority to enable him to act on the absentee's behalf in protecting property, caring for dependents and satisfying obligations left behind. Distribution should occur at a time or under circumstances which reasonably indicate that the absentee will not return, and the distribution scheme should in some manner provide for the possibility of the absentee's return.

As a model for the furtherance of such ends, the recently enacted North Carolina act appears to be the most satisfactorily equipped statute to date. By making final distribution the last act in a receiver-

\footnotetext{
184 N.C. GeN. Stat. § 28A-18(b) (Supp. 1965).

${ }^{186}$ Some insurance contracts provide that suit must be brought within one year after the death of the insured. 1942 Wis. L. REv. 280, 283-84. This type of provision would pose difficult problems for those who rely on a period of unexplained absence to establish death. Although a decree of death may, for example, be obtained at the end of seven years, the court may determine the date of death as being three years previous to the decree. Such an insurance contract would by its terms prevent collection. Id. at 284 .

The majority rule in states employing a presumption of death statute is that the statute of limitations is suspended until the termination of the presumptive period. Presumably this would also be true in states employing a statute of limitation absentee statute. See $i d$. at 285.

The Uniform Act attempts to solve this problem by declaring that such shortened periods of limitation are of no effect. UNIFORM ABSENCE AS EvidENGE OF DEATH AND Absenters' Property Act $\$ 2$.

190 The North Carolina act specifically provides that the court-appointed receiver is to pay insurance premiums. N.C. GEN. STAT. $\S 28 A-8$ (4) (Supp. 1965). By so providing, the policy will not lapse through nompayment during the statutory five-year period of limitation. If at the end of this time death is found to have occurred three years prior to tbe expiration of the limitation period, the estate would presumably be entitled to a refund of premiums paid after the determined date of death.
} 
ship scheme, the property can be conserved during the running of the time before final distribution can be made. In addition, the unique features relating to conservation and administration of small estates, disposal of life insurance policies of the absentee, and the absentee insurance fund all extend adequate coverage to problems which had previously perplexed the states. It is suggested that older statutes which appear inadequate in light of modern conditions might efficaciously be revised along the lines of the North Garolina statute.

$$
\begin{aligned}
& \text { t.s.p. } \\
& \text { j.w.d. }
\end{aligned}
$$

